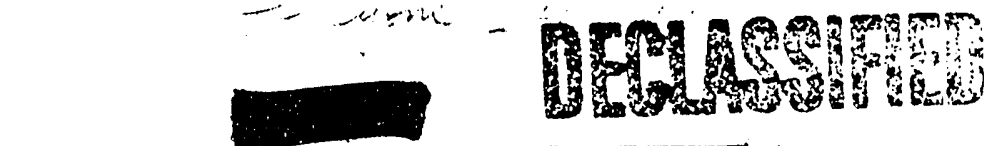 HANFORD TTECHFICAL RECOHS GENERAL (g. ELETRIC
}

HANFORD ATOMIC PRODUCTS OPERATION - RICHLAND, WASHINGTON

$\mathrm{HW}--48447$

DE93 009994

SERIES AND COPY NO.

32

DATE

February 14, 1957

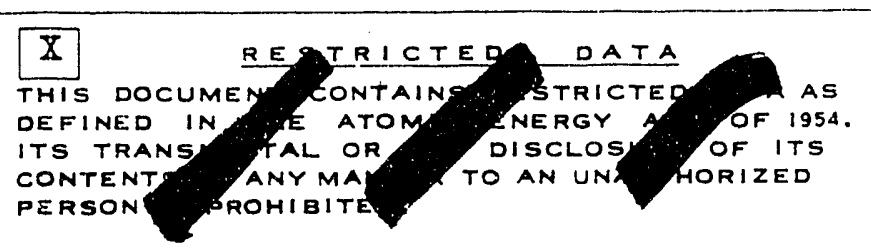

OTHER OFFICIAL CLASSIFIED INFORMATION THIS MATERIAL CONTAINS INFORMATION AFFECTING the national defENSE of the united states WITHIN THE MEANING OF THE ESPIONAGE LAWS. TITLE 18, U.S.C., SECS. 793 AND 794, THE TRANSMISSION OR REVELATION OF WHICH IN ANY MANNER TO AN UNAUTHORIZED PERSON IS PROHIBITED BY LAW.
TITLE

Revision of Horizontal Control Rods to Permit Ut1lization of Neutrons for ByProduct Production, 105-C, 105-KE, 105-KW

\section{G. A. NoweII}

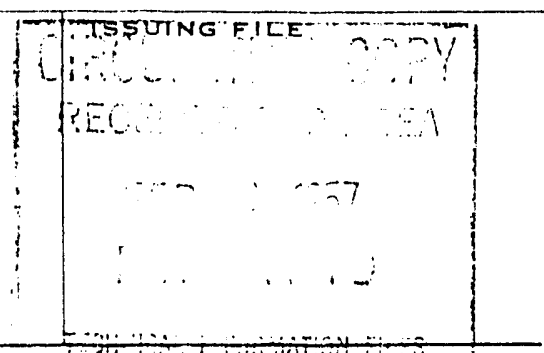

THIS DOCUMENT MUST LEFT UNATTENDP

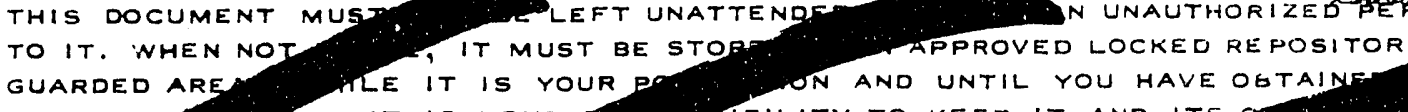

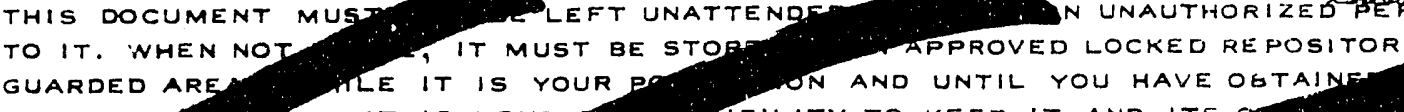
CLASSIFI ITS IT IS YOUR ASIBILITY TO KEEP IT AND ITSAM

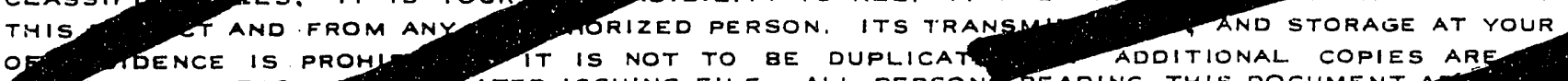

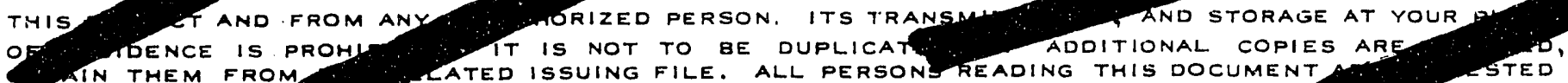
TO SIGN IN THE SPAD HOVIDED BELOW. ROUTE TO: PAYROLL. NO. FILESROUTE SIGNATURE AND DATE

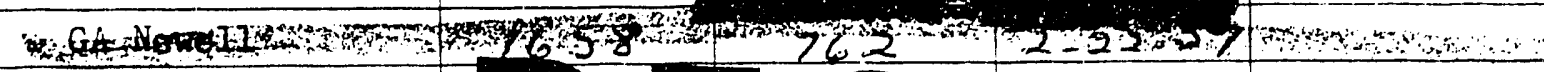
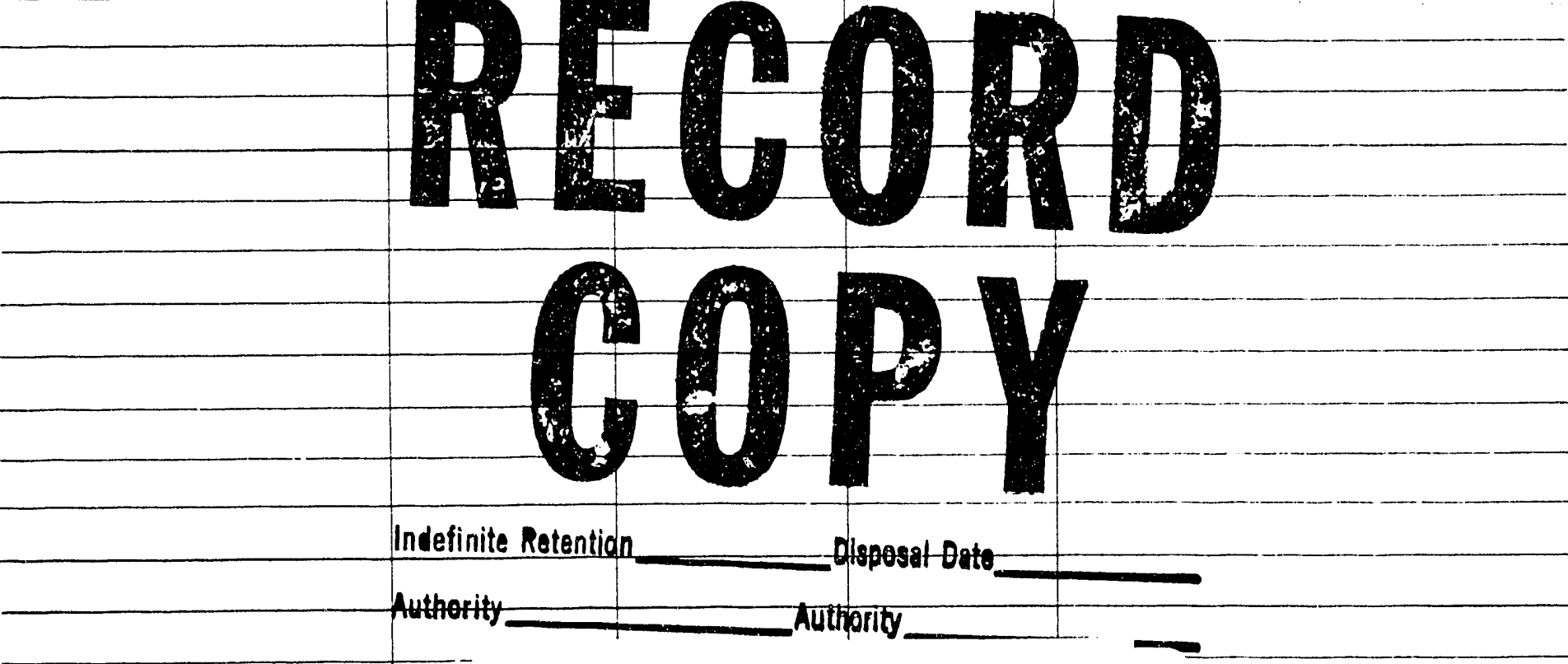


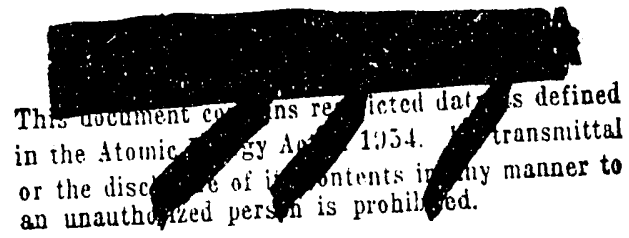

\section{HW -48447}

Po.ge 1

or the disc an of on is probil.

BUDGET STUDY REPORT

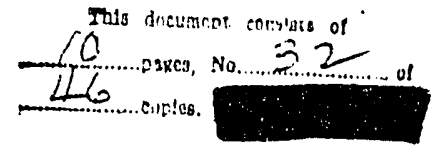

FY-1959 PIANT AND EQUIPMENT BUDGET

\section{APPROVAL SHEET}

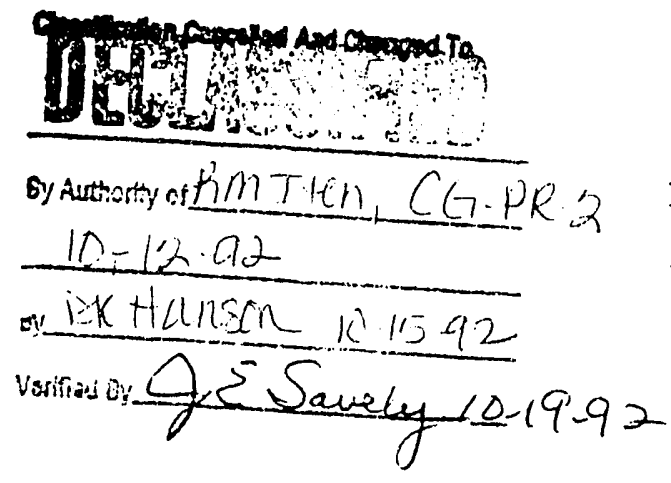

February 14, 1957

Budget Item No. B-5593I

TITIE: REVISION OF HORIZONTAL CONTROL RODS TO PERMIT UTILIZATION OF NEUTRONS FOR BY-PRODUCT PRODUCTION - 105-C, 105-KE, and 105-KW.

ENGINEERING BY s. A.2.2eweel Date $2-18-57$

APPROTED BY
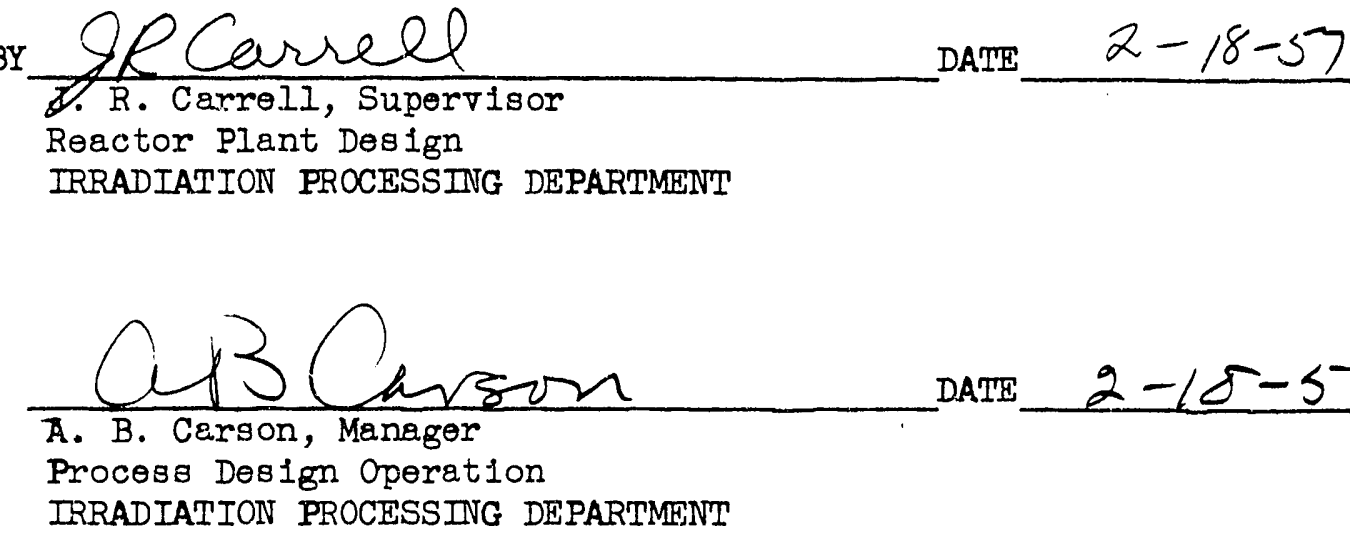

DATE

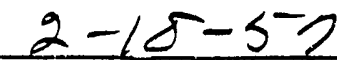

Procesa Design Operation

IRRADIATION PROCESSING DEPARTMENT

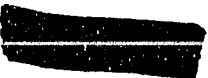

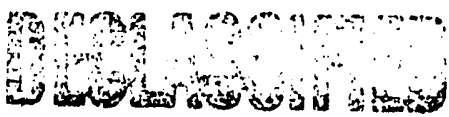

DETRARTON REETAWTEO TO US. OILY 
HW -48447

Page 2

BUDGET STUDY REPORT

FY-1959 PLANT AND EQUIPMENT BUDGET

\section{DISCLAIMER}

\begin{abstract}
This report was prepared as an account of work sponsored by an agency of the United States Government. Neither the United States Gnvernment nor any agency thereof, nor any of their employees, makes any warranty, express or implied, or assumes any legal liability or responsibility for the accuracy, completeness, or usefulness of any information, apparatus, product, or process disclosed, or represents that its use would not infringe privately owned rights. Reference herein to any specific commercial product, process, or service by trade name, trademark, manufacturer, or otherwise does not necessarily constitute or imply its endorsement, recommendation, or favoring by the United States Government or any agency thereof. The views and opinions of authors expressed herein do not necessarily state or reflect those of the United States Government or any agency thereof.
\end{abstract}

February I4, 1957

Budget Item No. B-55931

REVISION OF HORIZONTAI CONTROL RODS TO PERMIT UTILIZATION OF NEUTRONS FOR BY-PRODUCT PRODUCTION $105-\mathrm{C}, 105-\mathrm{KE}, \& 105-\mathrm{KW}$

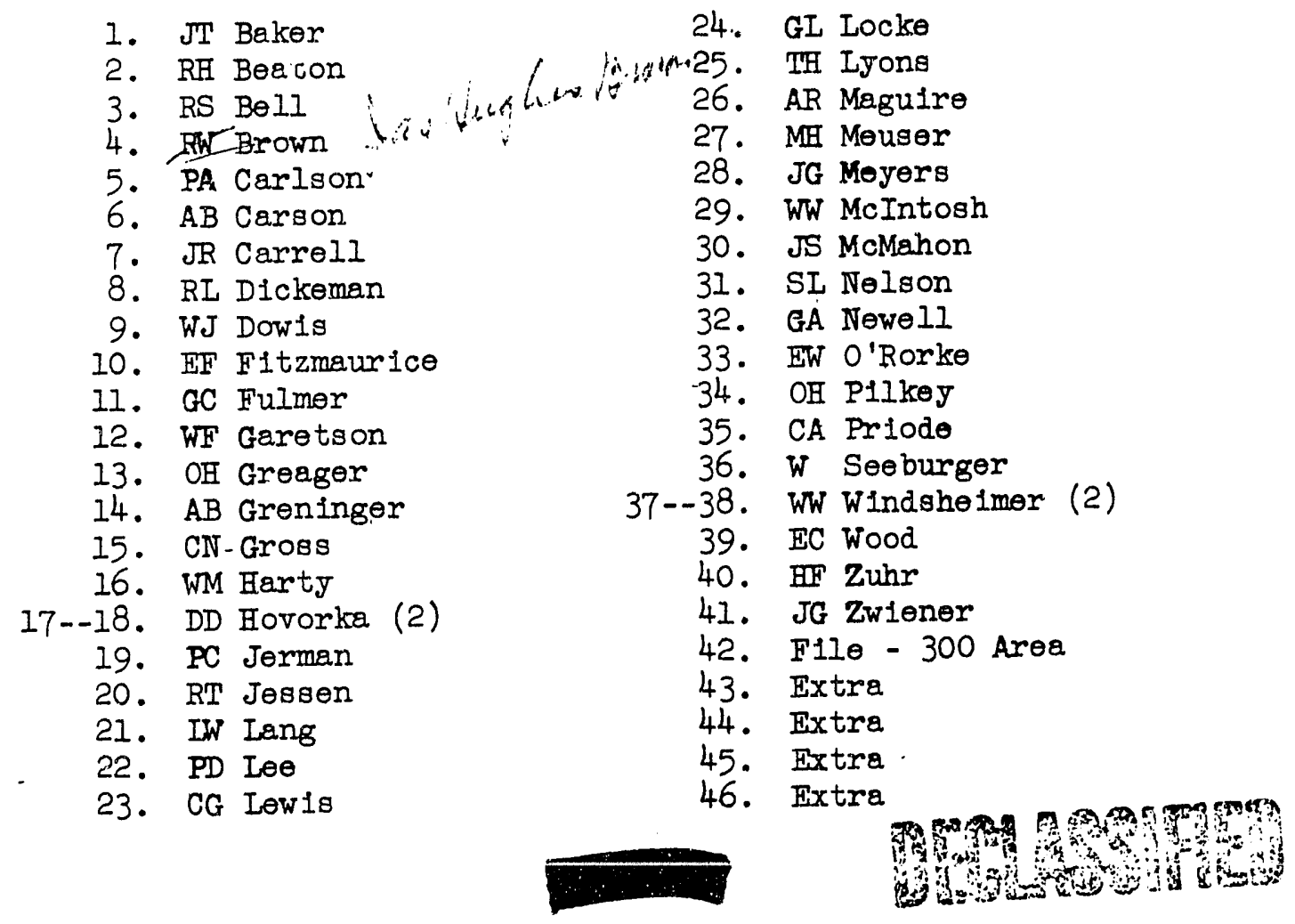




\section{BUDGET STUDY NO. B-55931}

\section{IIVTRODUCTION}

\section{A. Purpose}

The purpose of this budget study is to analyze the problems involved at 105-C, 105-KE, and 105-KW Bulldings to revise the existing horizontal control rods to permit utilization of neutrons for byproduct production, compare alternate solutions, and provide necessary budget data on the proposed solution. The sponsor of this budget study is Reactor Operations.

B. Background

Each of the Hanford reactors has a certain amount of its reactivity reserved for control which is necessary to maintain the power level and to adjust ine flux distribution within the reactor. A large percent of this reserve activity (avallable neutrons) is not used for product or by-product production but is absorbed by the horlzontal control rod system.

It has been recognized that with the proper selection of rod control material and a revised rod design this reactivity normally controlled by the rods could be used for control and at the same time could produce a by-product.

C. Scope of Study

The scope of this study will include the investigation of tine feasibility and the financial justification for by-product production in the horizontal control rods. Time limitations prevent the inclusion of more than one sketch in this report. Calculations will be made to check the physics problems involved and a study will be made of available information pertaining to the problems involved.

\section{RECOMMENDATIONS AND CONCLUSIONS}

It is recommended that reviaions be made to the horizontal rods in $105-\mathrm{C}, 105-\mathrm{KE}$, and 105-KW Bufld ings and all other neceseary equipment be procured and installed to permit tritium by-product production by the irradiation of lithium-aluminum slugs in the rods. The revisions are justified by. increasing the reactor production by producing tritium as a by-product without decreasing plutonium production.

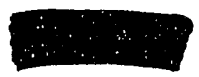


EWW-48447

Page 4

III. STATEMETN OF THE PROBLEM

The problem, involving the existing horizontal rods, is to increase the production of the reactors by utilizing the neutrons normally used to control the reactor, for by-product production also. The byproduct would be produced without a change in power level or plutonium production and would not require additional uranium fuel.

IV. DESCRIPTION OF ALTERNATE SOLUTIONS

A. Solution No. I

The recommended solution for by-product production is to revise the horizontal rods to permit 10 percent lithium-aluminum alloy slugs to bo irradiated in them when they are insorted in the reactor for control purposes.

The revision would requixe replacing ix existing rods in each " $\mathrm{K}$ " Area, and three rods in " $\mathrm{C}$ " Area with new rods with a new tip section design. The tip section of the new rod would consist of a ribbed inner aluminum process tube into which 2-inah diameter slugs would be charged. This process tube would have two ribs on the inside for centering the slugs and three ribs on the outside for centering it in the aluminum tube forming the outside casing of the rod. See Sketch No. SP-8044 which is attached.

The cooling water would flow through tubing ill the seal section as it presently does, enter end flnw through the outer anmulus to the tip end of the rod. It would then return through the annulus between slugs and inside diamoter of the process tube to the tubing in the seal section and out of the rod through a hose as with the existing rods.

The 105-K rod diameter would be increased to 3-inch 0.D. from 2-5/8inch $0 . D$. to accomodate the 2-inch diameter by 9 -inch long slugs. The graphite channel in the reactor would have to be replaced toraccommodate the larger rod and the various rod guides and bearings would be revised also. The drive mechanism would be ralsed in elevation to accommodete a 3-inch diameter rod. No graphite channel, guides, or bearings would be changed at "C" Area since existing rods are already 3-inch O.D.

The joint between the tip and seal section of the new rods would be dosigned for easy separation for charging and discharging slugs. The joint would be separated in the outer rod room near the barricade wall and a special discharging mochanism would bo attached for discharging the olugs. The mechanism would direct high pressure water into the rod tip outer annulus for flushing the slugs through the mechanism and through a tube into a cask on the floor directly bolow. Slugs would remain in the cask for approximately

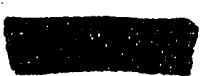




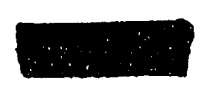

HW -48447

Page 5

two weeks or until they cool off enough to be transferred to the reactor storage basin for storage. A discharge mochanism and two casks would be required for each area.

B. Solution No. 2

An alternate method for producing tritium as a by-product would use the helium-three isotope gas in the rods for the absorbing material. The hellum-three gas would bo piped into the rod tip and instead of the rod moving in or out to vary the effect of the rod, the pressure of the hellum would be varied. No movement of the rod would bo necessary.

V. EVALUATION OF ALTTERNATE SOLUTIONS

Ractor control and by-product production with helium-throo gas was refocted because of the lack of any experience with this type of a control system which necesserily means that considerable development work would be required before it could be proved useful2 ${ }^{2}$. Th1s system would require a gas-tight system. A personnel hazard would exist if significant quantities of tritium wer $\theta$ lost from the system. Uncertainties also exist in the availability, handing, and storage of helium-three gas.

VI. DETAIIED JUSTIFICATION OF PROPOSED WORK

The justification for the installation of the new control rods is based on increasing the ector production by producing tritium as a by-product without a decrease in plutonium production. The amount of tritium that can be produced in the control rods has been calculated to be 96 grams per year for one " $K$ " reactor and 51 grams per year for one " $\mathrm{C}$ " reactor". The production rate is based on the rod patterns and positions presently being used for each of the reactors.

A. 105-KE and 105-KW - Justification of Proposed Work

Each " $K$ " reactor is using eleven rods for control. A portion of the length of each rod (varies from rod to rod from 20 to 95 percent of the rod length), remains in the reactor at all times. Ninety-six percent of the tritium would be produced by $\theta 1 x$ of the rods which remain inserted 75 to 95 percent of their length. The revisions would be made to these six rods. $* * * * * * * * * * * * * * * * * * * * * * * *)+\cdots * *$

I. I.W. Iang - HW-22977 - Report of Invention, dated December 12, 1951.

2. P.H. Reinker - HW-27499 - "Evaluation of $\mathrm{HE}^{3}$ Control System", dated March 25, 1953.

3. W.R. Smit - HW-48133 - Tritium Producing Control Rods at " $K$ " and "C" P1les, dated February 1, 1957.
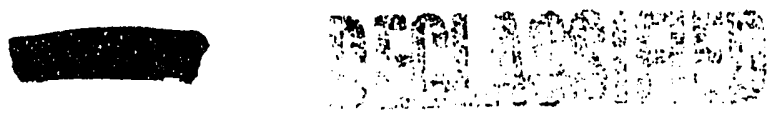
HW -48447

Page 6

If tritium is worth its gram equivalent of plutonium, the tritium produced in one " $K$ " reactor per year in six rods would be worth $\$ 306,000$.

The estimated cost for the installation of new rods and pertinent equipment is $\$ 1,025,000$ for two " $K$ " reactors.

It is estimated that two rods can be installed during a regular discharge shutdown plus one extre day dowatime. Work on the rods would not interfere with regular charge-discharge operations, since the work would be done by Minor Construction forces in the rod rooms. Six rods would require a total of three days downtime chargeable to the rod installation. With a value of $\$ 28,000$ per day placed on lost reactor production time, a total of $\$ 84,000$ production loss would be charged against each " $K$ " reactor installation.

The total cost of the installation for both " $K$ " reactors including the cost of downtime, would be $\$ 1,193,000$.

It is estimated that the cost of new slugs and manpower to charge all of the rods, an average of $1-\frac{1}{2}$ times a year, would be $\$ 30,000$ per " $K$ " reactor.

With an estimated total installation cost of $\$ 1,193,000$ for both " $K$ " areas and an estimated tritium value of $\$ 552,000$, the amortization period would be 2.17 years.

\section{B. 105-C Justification of Proposed Work}

"C" reactor is presently using five rods for control. The portion of each rod remaining in the reactor varies from 10 to 80 percent of its length. EightJ-five percent of the product would be produced by three rods which always remain inserted 80 percent of their length. These three rods would be revised.

If the tritium is worth its gram equivalent of plutonium, the tritium produced in "C" reactor per year in three rods would be worth $\$ 162,000$. The estimated cost for the installation of the new rods and auxiliary equipment at "C" reactor would be $\$ 305,000$.

It is estimated that the cost of new slugs and manpower to charge each of the rods an average of $1-\frac{1}{2}$ times a year would be $\$ 15,000$.

With an estimated total installation cost of $\$ 305,000$ for "C" reactor and an estimated tritium value of $\$ 147,500$, the amortization period would be 2.07 years.

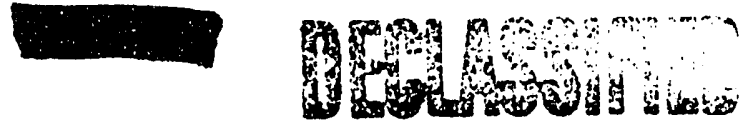




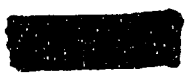

HW -48447

Page 7

VII. SCHEDULES

$\underline{\text { Start }}$

Complete

Development of slugs and discharge mechanism

Design

Procurement

$1-1-58$

$1-1-58$

$5-1-58$

Construction

$7-1-58$

Beneficlal Use

$2-1-59$

$3-1-59$

$6-1-59$

In order to start procurement of long delivery ltems promptly on July I, 1958, it would be adviaable to advance the starting date for deslgn and development to January 1958.

If this profect is deferred to start procurement later than July I, 1958, all dates on above schedule, includine beneficial use, will be delayod accordingly.

VIII. AGKNOWIEDGEMEINTS

I.'W. Lange - Process and Reactor Development

W. R. Smit :- Process Design

E. R. Astley - Process Design

J. W. Tlinehens - Estimating

G.' C. Fulmer - Operational Physics

R. W. Brown - Plant Production and Scheduling

J. W. Dodds - Mechanical Development

R. O. Bungge - Operationel Physics

IV. APFENDIX

Project Cost Estimate, 105-K

Project Cost Estimate, I'05-C

Sketch - SP-8044 - Horlzontal Control Rod for By-Product Production, 105-C and 105-K.

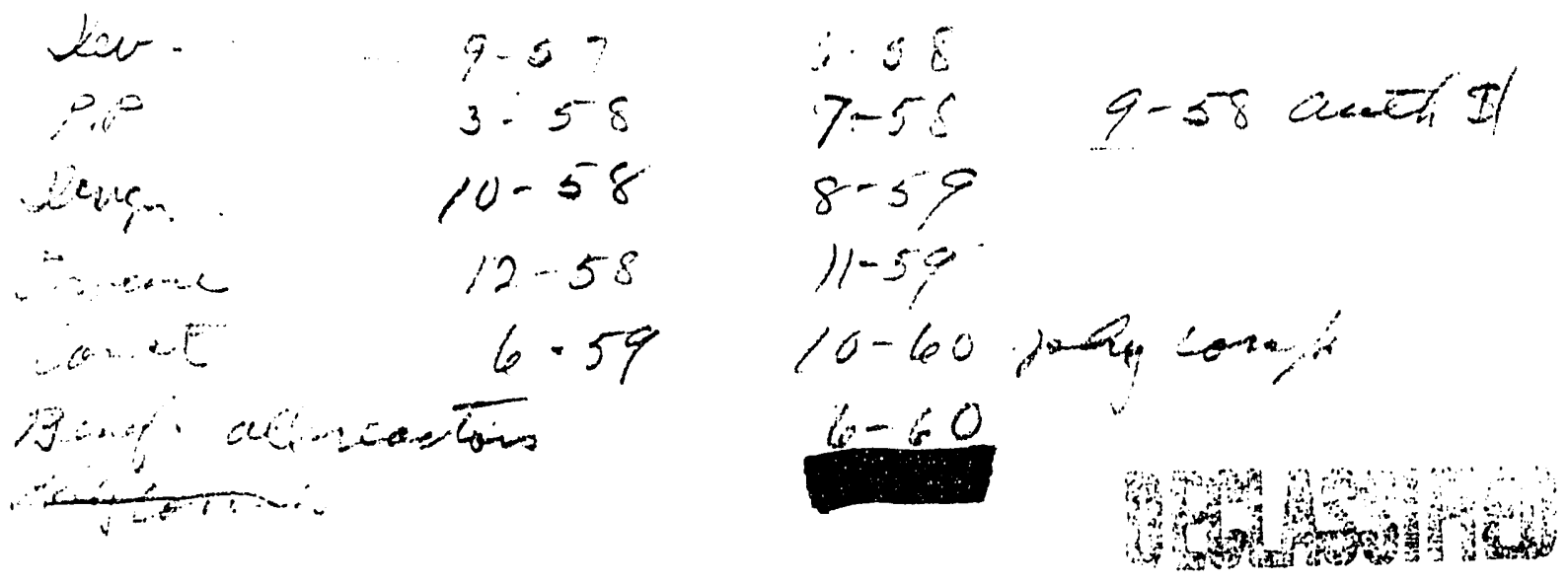




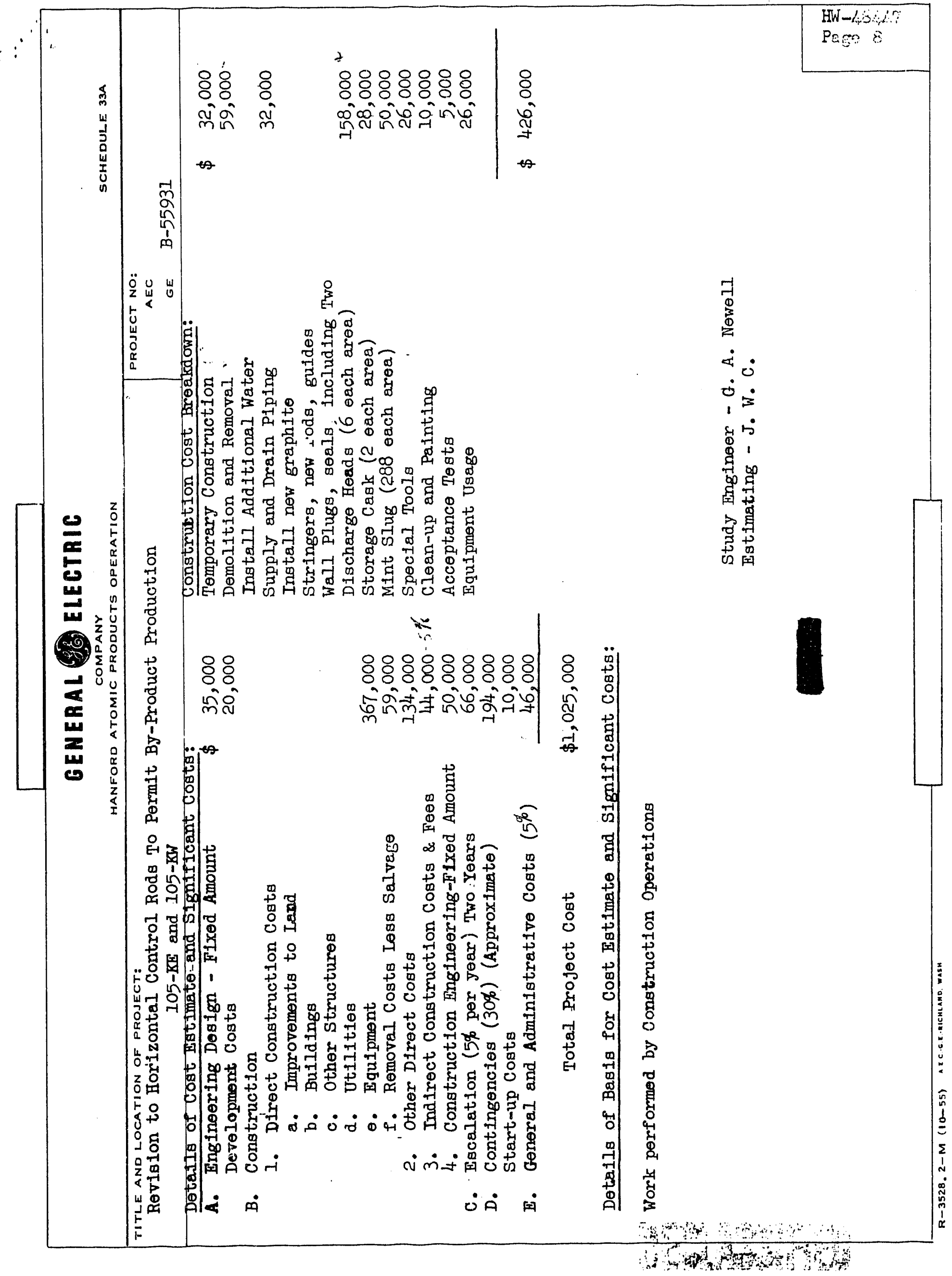




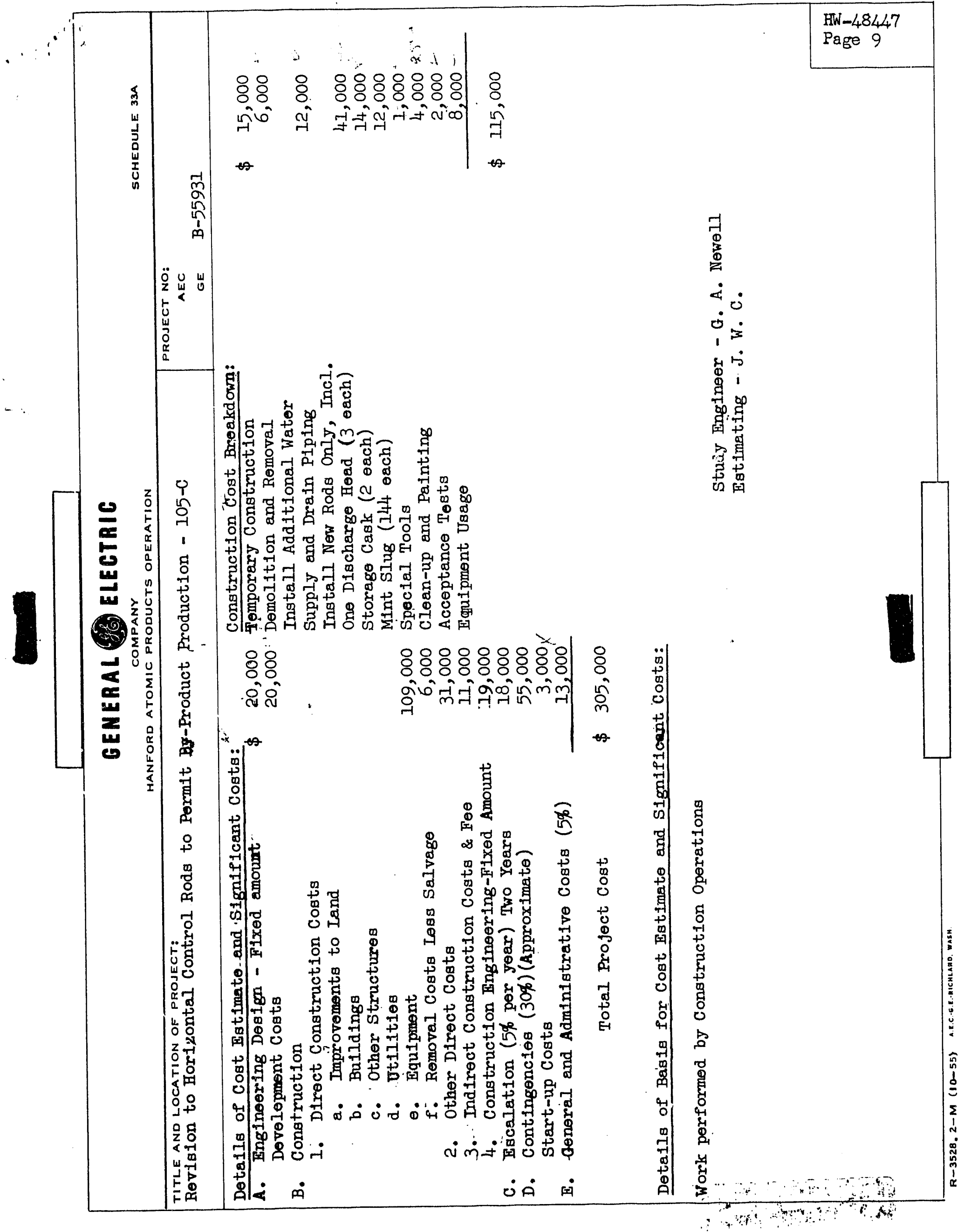




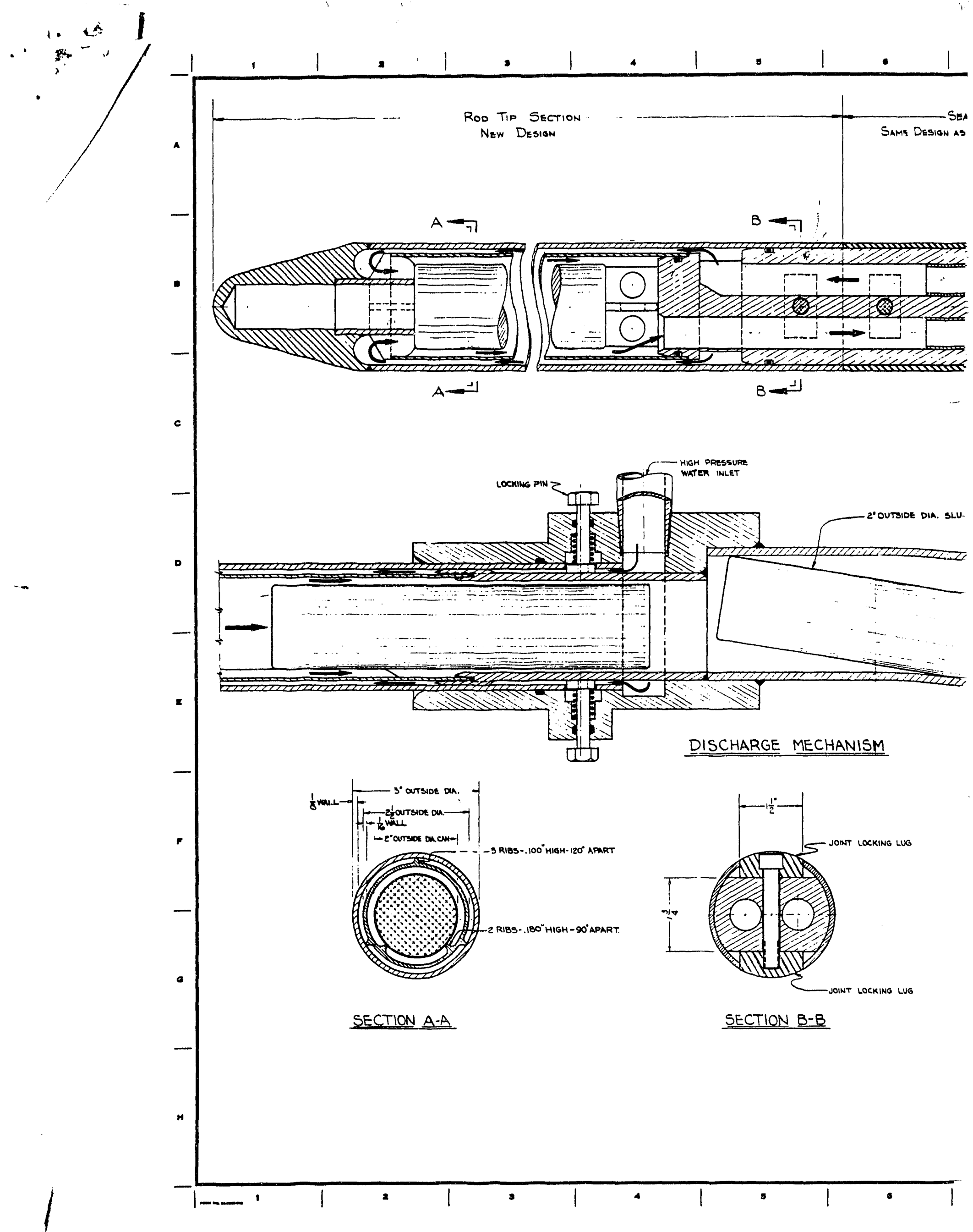


- Seal section in 'k' Rod Omy jesian as Present Except lamber Dia.

Rack SECTION

$10 \quad \mid$
SECTION

HW-48447 " 1 PAGE / 0 Same as Prosent Design
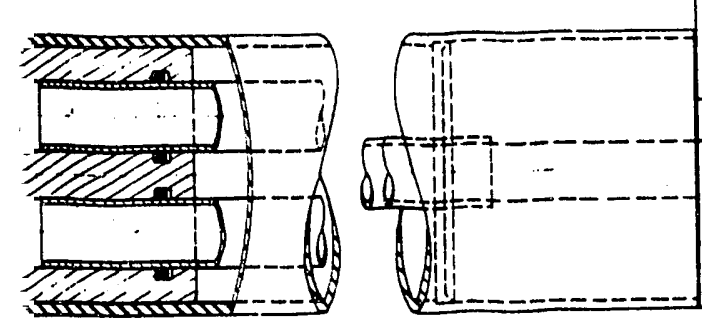

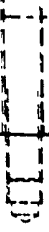
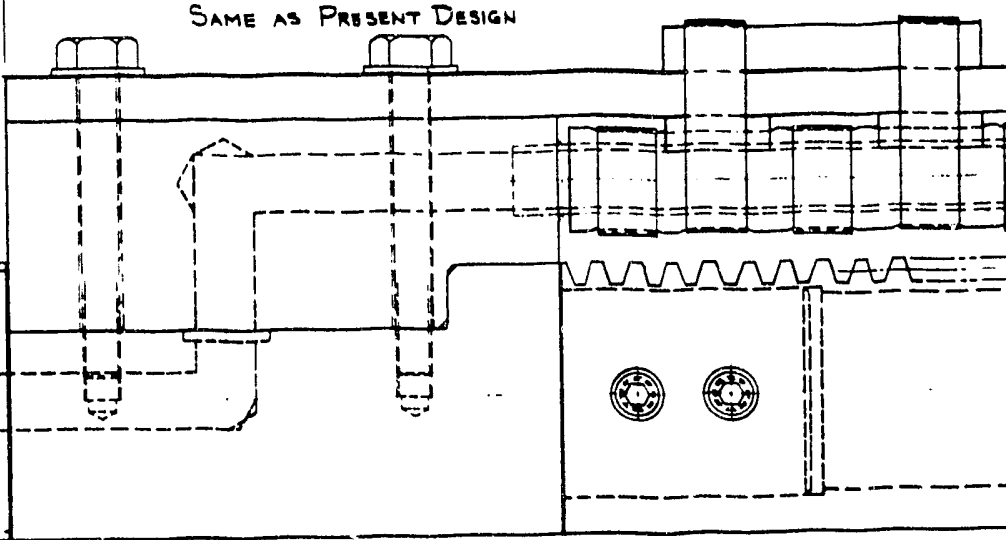

DIA. SLUE 

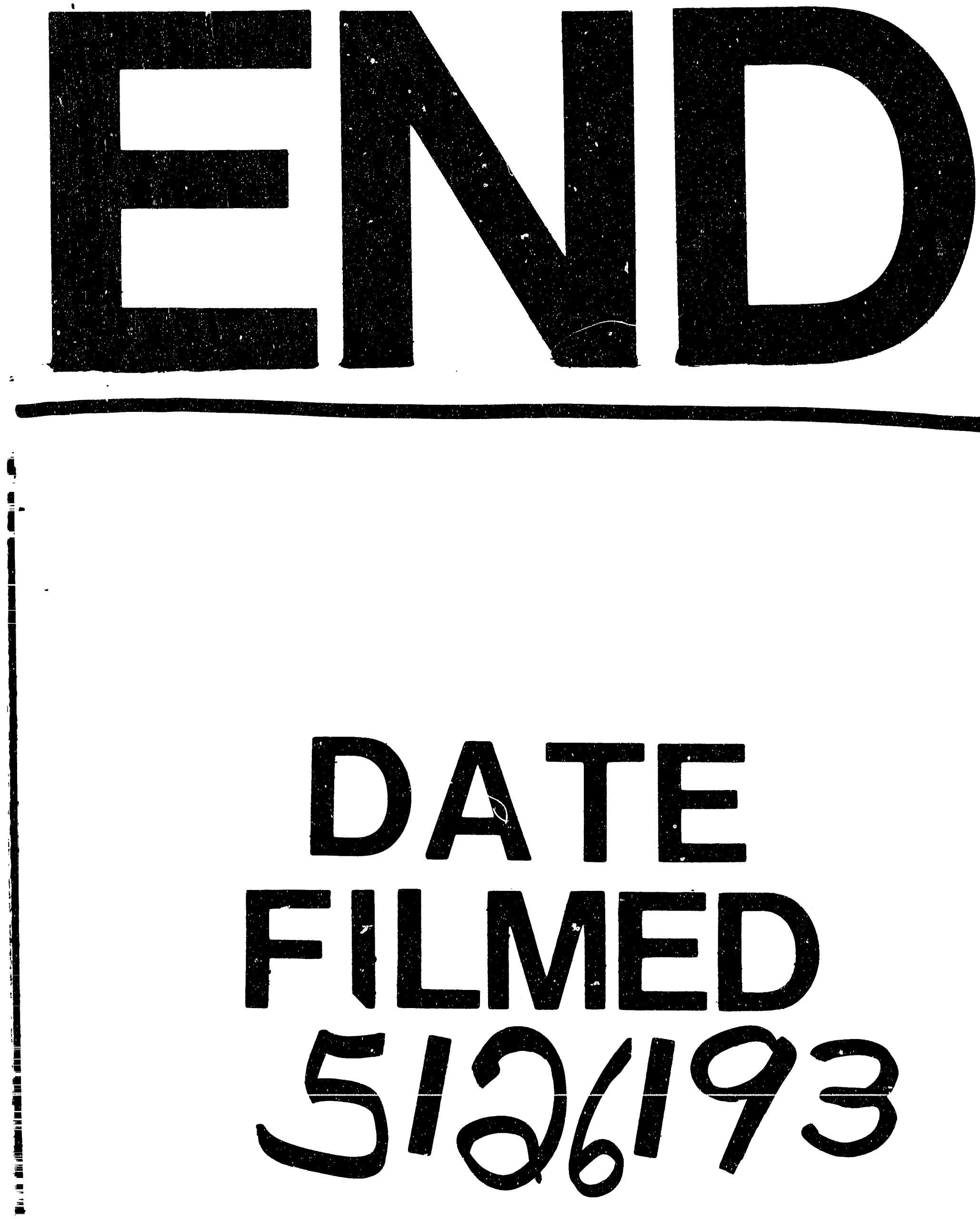
1 